\title{
The Impact of Allogeneic Hematopoietic Cells Transplantation on Female Reproductive Health: A Short Review
}

\author{
Ana Tikvica Luetić ${ }^{1,2}$, Nikolina Gusićn ${ }^{3}$, Dubravko Habek ${ }^{1,2}$ \\ ${ }^{1}$ Catholic University of Croatia, Zagreb, Croatia \\ ${ }^{2}$ Clinical Department of Gynecology and Obstetrics, Clinical Hospital Sveti Duh, Zagreb, Croatia. \\ ${ }^{3}$ Department of Hematology, Clinical Hospital Centre Zagreb, Croatia
}

OPEN ACCESS

Correspondence: Prof Ana Tikvica Luetic, MD,PhD ana_tikvica@yahoo.com

This article was submitted to RAD CASA Medical Sciences as the review article

Conflict of Interest Statement: The authors declare that the research was conducted in the absence of any commercial or financial relationships that could be construed as a potentia conflict of interest.

Received: 17 April 2020 Accepted: 10 June 2020 Published: 22 July 2020

Citation:

Tikvica Luetic A, Gusić, Habek D. Th Impact of Allogeneic Hematopoietic Cells Transplantation on Female Re productive Health: A Short Review.

RAD CASA - Medical Sciences. 543=50-51 (2020): 57-62 DOI: https://dx.doi.org/10.21857/ y26kec48v9

Copyright (C) 2020 Tikvica Luetic, Gusic and Habek. This is an open-access article distributed under the terms of the Creative Commons Attribution License (CC BY). The use, distribution or reproduction in other forums is permitted, provided the original author(s) and the copyright owners(s) are credited and that the original $(S)$ are credin this journal is cited in accordance whit accepted adacemic practice. whit accepted adacenic practice. No use, distribution or reproduction is

\section{ABSTRACT:}

Hematopoietic Stem Cell Transplantation (HSCT) has been widely used fore decades as the most effective treatment of several malignant and non-malignant hematological diseases. Among many complications with occurrence after HSCT procedure, reproductive issues are often neglected although these can adversely affect the patient quality of life. The most common gynecological complications after HSCT include: ovarian insufficiency, increased risk of cervical atypia and carcinoma, thrombocytopenia-associated menorrhagia, genital involvement of graft versus host disease, osteoporosis, fertility and pregnancy issues etc. Due to their relevance to the patients and constant growing of life expectance of women after HSCT it is of huge importance to diagnose and treat reproductive complications after the transplantation procedure by multidisciplinary approach.

KEYWORDS: Allogeneic hematopoietic cells transplantation, reproductive complications, ovarian insufficiency

\section{SAŽETAK:}

UTJECAJ ALOGENE TRANSPLANTACIJE HEMATOPOETSKIH STANICA NA REPRODUKTIVNO ZDRAVLJE ŽENA: KRATKI OSVRT

Transplantacija krvotvornih matičnih stanica (engl. HSCT) široko se koristi desetljećima kao najučinkovitiji tretman nekoliko zloćudnih i nemalignih hematoloških bolesti. Među mnogim komplikacijama koje se javljaju nakon HSCT postupka, reproduktivna su pitanja često zanemarena, iako ona mogu negativno utjecati na kvalitetu života pacijenta. Najčešće ginekološke komplikacije nakon HSCT-a uključuju: insuficijenciju jajnika, povećani rizik od atipije i karcinoma cerviksa, menoragije povezane s trombocitopenijom, zahvaćenost transplantata u odnosu na domaćina, osteoporozu, plodnost i trudnoću itd. Zbog njihove važnosti za pacijente i konstantne rast očekivanog života žena nakon HSCT-a od velike je važnosti dijagnosticirati i liječiti reproduktivne komplikacije nakon postupka transplantacije multidisciplinarnim pristupom.

KLJUČNE RIJEČI: Alogena transplantacija krvotvornih stanica, reproduktivne komplikacije, insuficijencija jajnika 


\section{INTRODUCTION}

Allogeneic hematopoietic cell transplantation (HCT) is a widely used medical procedure for treatment of a different hematologic diseases. Around $85 \%$ of HCT is performed for curing malignant diseases, such as acute and chronic leukemias and lymphomas, while the rest of the procedures is used for diverse non-malignant states like aplastic anemia or immunodeficiency ${ }^{1}$. Progress in this medical field regarding patient and donor selection, stem cell isolations, supportive care, prevention of different complications and decreased-toxicity of preparative procedures resulted in expansions of the indications for HCT and number of patients treated by this method. On the other hand, the numbers of long-term survivors following hematopoietic stem cell transplantation have been notably increasing in last decade. In modern medicine it became mandatory to consider not only the survival rate, but also the quality of life of patients after HCT. Approximately $40 \%$ of these patients are female and the aspect of their gynecological health could not be neglected ${ }^{2}$. Complications of HCT vary upon of many factors such as preparation procedures before the transplantation, age of the patient, comorbidity, primer disease, time of transplantation and many other clinical characteristics ${ }^{3}$. Complications of HCT can be divided into two main groups upon the onset time: early complications that develop in the first 100 days after the procedure and late that occur after that time. Early complications include: hemorrhagic cystitis, veno-occlusive disease, thrombotic microangiopathy and different respiratory complications. Infections that could be bacterial, viral and fungal could also involve all organs and systems and its prevention and treatment is of major concern for survival and life quality. Graft versus host disease (GvHD) that could develop as an early and late complication is very serious event and among leading causes of death along with relapse of the underlying primary disease and infections. Late complications can involve almost every organ disturbing later life such as cataract, arrhythmia, osteoporosis, diabetes, dental problems etc.

Female reproductive system has been shown to be highly predisposed to the effect of HCT procedure. These complications have later onset and include: premature menopause, genital type of GvHD, cervical carcinoma, human papilloma virus reactivation, vaginal infections and sexual dysfunctions. It is clear that allogeneic HCT has negative impact on fertility often causing premature ovarian insufficiency and infertility, and even complicating possible pregnancy. All the mentioned gynecological problems negatively impact the quality of women life after HCT which should be considered and prevented multidisciplinary. In this review we will discuss the impact of allogeneic HCT on female reproductive system with special considerations on longterm consequences.

\section{THE EFFECT OF ALLOGENEIC HEMATOPOIETIC CELL TRANSPLANTATION ON OVARIAN FUNCTION}

It is well known that HCT procedure and its previous preparation management effect ovarian functions at several levels. This negative influence on ovaries impact the female well being, health and fertility demanding gynecologic care at several stages and collaboration between health professionals ${ }^{4}$. The most important potential consequence of HCT procedure is ovarian insufficiency which is characterized by loss of ovarian function with hypergonadotropic hypogonadism, decreased uterine and ovarian volumes and most prominent symptom of secondary amenorrhea. Our results have also confirmed elevated levels of follicle stimulating hormone (FSH) and luteinizing hormone $(\mathrm{LH})$ in women who underwent HCT as compared to controls 5 . Ovarian insufficiency is most common complication affecting more than $90 \%$ of patients depending on age and therapeutical regimens ${ }^{6}$. In our study all the patients were affected probably due to the advanced age since median age was 42 years ${ }^{5}$. The exact mechanism of HCT impact on ovarian function has not yet been elucidated, although pretransplant conditioning regimen has been well appreciated. Indeed, conditioning regimens that include high-dose alkylate treatments associated or not with total body irradiation can severely damage the ovaries ${ }^{7}$. On the other hand, reduced-intensity conditioning did not result in significant improvement of ovarian function pointing that other mechanism could be involved in the subject ${ }^{8}$. It has been shown that even graft-versus-host disease could target granulosa cells of the ovarian follicles, thereby significantly reducing fertility and causing ovarian insufficiency ${ }^{9}$. This explains why pharmacological GVHD prophylaxis could help in preserving fertility after $\mathrm{HCT}^{9}$. In addition, long-lasting steroid treatment used in GvHD management can have additional negative impact on ovarian function ${ }^{10}$.

Ovarian insufficiency is not always irreversible condition with younger age and higher estradiol levels being positive predictors of ovarian restoration ${ }^{11}$. Advanced age is independent risk factor, with the age of 30 being consider as cut-off value for irreversible ovarian damage ${ }^{10}$. Underlying disease has also influence on ovarian failure since it has been shown that acute lymphoblastic leukemia and lymphoma increase the risk of premature menopause $^{10}$. As expected allogeneic transplantation also increased the risk of ovarian damage as compared to autoimmune transplantation.

Since ovarian insufficiency is characterized by various symptoms of estrogen depletion, such as hot flushes, mood disorders, sleep disorders, etc, what negatively impact the quality of life it is important to prevent, diagnose and treat this disorder.

\section{THE EFFECT OF ALLOGENEIC HEMATOPOIETIC CELL TRANSPLANTATION ON CERVIX}

It is well known that immunocompromised women, including those after hematopoietic stem cell transplantation, have an 
increased risk of cervical cancer ${ }^{12}$. Since this mainly squamous carcinoma develops in stepwise pattern, it is reasonable that different grade squamous intraepithelial lesions also occur with higher prevalence after HCT procedure ${ }^{13}$. We have shown that less than $4 \%$ of patients after HCT have normal results of cervical Papanicolaou smear as compared to $76 \%$ in general population $^{5}$. Similar results have been published by Negri and coworkers who extended the surveillance of patients and have shown the regression of the changes in many cases ${ }^{14}$. The addition of busulfan in chemotherapeutic regimens increased the number of abnormal cervical smears ${ }^{14}$. As expected, allogeneic HCT increases cervical abnormalities as compared to autogenic $\mathrm{HCT}^{15}$. Moreover, younger age and previous atypia in cervical Papanicolaou smears enhance the risk for post treatment abnormalities ${ }^{15}$. Recent study introduced the term therapy- related atypia that has been shown in around $11 \%$ of patients if cervical smear test was sampled within 100 days after $\mathrm{HCT}^{16}$. These cytological changes mimic precancerous lesions, but cervical surgical procedure and human papilloma virus tests were all negative. Repeated sampling showed the regression of cytological changes pointing that clinical informations are of crucial importance for patient management. All abnormal tests were found in patients treated by busulfan-containing chemotherapy, while no changes were observed after total body irradiation or nonbusulfan-containing chemotherapy ${ }^{16}$.

The pathogenesis of different cervical abnormalities include long-term chemotherapy, graft versus host disease and immunosuppressive therapy that all result in decrease cellular and humoral immunity. Although all these procedures have beneficial roles in transplant protection, they also predispose patients to different bacterial and viral infections, such as human papilloma viruses that are in the basis of all cancerous cervical changes. It is unclear weather newly found cytological abnormalities are the results of new infections or reactivations of latent HPV virus in the setting of immunosuppression ${ }^{17}$. In addition, genital GVHD and unrelated HLA-matched donor were shown to be risk factors for developing cervical cytological abnormalities ${ }^{17}$. Opposite from mild cervical cytologic abnormalities, Holowaty et al. have reported the risk of progression for moderate dysplasia was $16 \%$ within 2 years and $25 \%$ within 5 years (18). The risk for cervical carcinoma was significant within 2 years after the abnormal Papanicolaou smear test ${ }^{18}$. Moreover, it has been shown that patients after HCT have double risk for occurrence of solid tumors in a period of 10 years as compared to general population with GVHD being an independent risk factor for squamous cell carcinoma ${ }^{19}$.

\section{OTHER REPRODUCTIVE ISSUES AFTER HEMATOPOIET-} IC CELL TRANSPLANTATION

It is well known that different modalities of treatment used in procedure of HCT effectively destroy the patient's bone marrow with subsequent pancytopenia which can result in severe morbidity. One aspect of this condition is thrombocytopenia which can induce thrombocytopenia-associated menorrhagia, particularly in women who had experienced irregular vaginal bleeding before the HSCT ${ }^{20}$. On the other hand, it has been shown that there is no correlation between severe menorrhagia and a general bleeding predisposition in other body sites ${ }^{21}$. Although thrombocytopenia-associated menorrhagia can affect up to $40 \%$ of patients undergoing HCT and can severely affect the morbidity and life quality of those patients, there are only few publications on the most effective treatment of this condition ${ }^{21-23}$. Beside the tranexamic acid that has been used for the treatment of menorrhagia of different origin, other effective treatment for thrombocytopenia-associated menorrhagia include gonadotropin-releasing hormone analogues and depo-medroxyprogesterone acetate $^{21}$. It is also advisable to perform initial pelvic sonogram to diagnose gynecologic disorders that can alleviate menorrhagia and to remove intrauterine device, since it can predispose for pelvic infections during a period of pancytopenia ${ }^{21}$. Chronic GVHD is a serious complication of HCT procedure that occur in $30 \%$ to $50 \%$ of transplants from human leukocyte antigens-matched siblings and $60 \%$ to $70 \%$ from matched unrelated donors ${ }^{24}$. This condition usually develops over several weeks and months and involving inflammation, cell-mediated immunity, humoral immunity and fibrosis in its etiology ${ }^{25}$. The most common affected organs are: skin, mouth, eyes, liver, and intestines. Genital tract is involved in around $25 \%$ of patients with mostly vulvar disease manifested as erosions and fissures ${ }^{26}$. Vulvar and vaginal scarring are less common complications that can result in vaginal obstructions and labial fusion ${ }^{27}$. Patients with these complications usually complain of genital pain, burning, dysuria, swelling, soreness, dryness and dyspareunia. The most effective treatment include: local estrogen therapy, topical steroids and immunosuppressants with surgery in most severe cases of disturbed anatomy.

Osteoporosis is another potential complication in patients undergoing HCT due to the several mechanism. The most common causal mechanism is the lack of estrogens associated with ovarian insufficiency, lack of ovulation and consecutive amenorrhoea $^{28}$. Other possible causes include different conditioning regimens, huge cytokine re-lease at the time of transplant, long-lasting immunosuppressive therapy and impaired intake and metabolism of calcium and vitamin D. Since osteoporosis can severely impact patient's morbidity and mortality, it is important to diagnose it and to start early treatment such as lifestyle modification, calcium and vitamin D supplementation, bisphosphonates and hormonal therapy ${ }^{29}$.

Due to the previously described ovarian insufficiency, fertility is severely impaired after allogeneic stem cell transplantation with estimated overall conception rate under $1 \%{ }^{30}$. Several factors contribute to this low conception rate. The most important 
negative factors are advanced age at the time of HCT and regimens that include busulfan. Nowadays, oncologic patients are interested in fertility preservation in general. There is a growing number of cases with successful procreation after malignancy including those using classical oocytes/eggs freezing procedure or novel strategies such as ovarian tissue freezing. It is clear that these techniques require multidisciplinary approach including oncologists, reproductive gynecologist, surgeons, and others.

\section{CONCLUSION}

Reproductive sequels are among most common complications after hematopoietic stem cell transplantation which negatively affect the quality of life both in short and long time periods after the procedure. On the other hand, these problems are often underestimated by professionals whose concern is more in overall survival and life-treating complications. Since due to the medical improvement life span after HCT is constantly growing, focus should be pointed to better recognition and treatment of different gynecological disorders enabling maximum reproductive health and procreation if possible. This should be a concern of different specialists ensuring better quality of life in patients after HCT procedure.

\section{LITERATURE:}

1 Gyurkocza B, Rezvani A, Storb RF. Allogeneic hematopoietic cell transplantation: the state of the art. Expert Rev Hematol. 2010;3(3):285-99. doi: 10.1586/ehm.10.21. PMID: 20871781; PMCID: PMC2943393.

2. Marty FM, Lee SJ, Fahey MM, Alyea EP, Soiffer RJ, Antin JH, Baden LR. Infliximab use in patients with severe graft-versus-host disease and other emerging risk factors of non-Candida invasive fungal infections in allogeneic hematopoietic stem cell transplant recipients: a cohort study. Blood. 2003;102(8):2768-76.

3. Giebel S, Labopin M, Socié G, Beelen D, Browne P, Volin L, Kyrcz-Krzemien S, Yakoub-Agha I, Aljurf M, Wu D, Michallet M, Arnold R, Mohty M, Nagler A. Improving results of allogeneic hematopoietic cell transplantation for adults with acute lymphoblastic leukemia in first complete remission: an analysis from the Acute Leukemia Working Party of the European Society for Blood and Marrow Transplantation. Haematologica. 2017;102(1):139-149.

4. Murphy J, McKenna M, Abdelazim S, Battiwalla M, Stratton P. A Practical Guide to Gynecologic and Reproductive Health in Women Undergoing Hematopoietic Stem Cell Transplant. Blood Marrow Transplant. 2019;25(11):331-343.

5. Gusić N. Kliničke i biokemijske značajke žena fertilne dobi nakon alogenične transplantacije krvotvornih matičnih stanica [Diplomski rad]. Zagreb: Hrvatsko katoličko sveučilište; 2018 [pristupljeno 08.03.2020.] Dostupno na: https:/urn.nsk.hr/urn:nbn:hr:224:481150 6. Tauchmanovà L, Selleri C, De Rosa G, Sammartino A, Di Carlo C, Musella T, Martorelli C, Lombardi G, Rotoli B, Nappi C, Colao A. Estrogen-progestin therapy in women after stem cell transplant: our experience and literature review. Menopause. 2007;14(2):320-30 7. Guida M, Castaldi MA, Rosamilio R, Giudice V, Orio F, Selleri C. Reproductive issues in patients undergoing Hematopoietic Stem Cell Transplantation: an update. J Ovarian Res. 2016;9(1):72. doi: 10.1186/ s13048-016-0279-y. PMID: 27802832; PMCID: PMC5088651 8. Komori K, Hirabayashi K, Morita D, Hara Y, Kurata T, Saito S, Tanaka M, Yanagisawa R, Sakashita K, Koike K, Nakazawa Y. Ovarian function after allogeneic hematopoietic stem cell transplantation in children and young adults given 8-Gy total body irradiation-based reduced-toxicity myeloablative conditioning. Pediatr Transplant. 2019;23(3):e13372.

9. Shimoji S, Hashimoto D, Teshima T. Graft-versus-host disease in the ovary potentially causes female infertility after allogeneic hematopoietic stem cell transplantation. Rinsho Ketsueki. 2017;58(7):827-834.

10. Orio F, Muscogiuri G, Palomba S, Serio B, Sessa M, Giudice V, Ferrara I, Tauchmanovà L, Colao A, Selleri C. Endocrinopathies after allogeneic and autologous transplantation of hematopoietic stem cells. Scientific World Journal. 2014;2014:282147.

11. Komura H, Kawaguchi H, Shimizu S, Yada-Hashimoto N, Shimizu M, Sato M, Inoue M, Ida S, Etani Y, Shoji Y, Nakacho M, Sawada K, Kimura T, Mitsuda N, Kurachi H. Ovarian insufficiency following allogeneic hematopoietic stem cell transplantation. Gynecol Endocrinol. 2017;33(2):156-159.

12. Nguyen ML, Flowers L. Cervical cancer screening in immunocompromised women. Obstet Gynecol Clin North Am. 2013; 40: 339-35. 13. Savani B.N. Stratton P. Shenoy A. Kozanas E. Goodman S. Barrett A.J. Increased risk of cervical dysplasia in long-term survivors of allogeneic stem cell transplantation-implications for screening and HPV vaccination. Biol Blood Marrow Transplant. 2008;14: 1072-1075. 14. Negri G, Casini M. Abnormal Cervical Cytology After Allogeneic Bone Marrow Transplantation. Am J Clin Pathol 2014; 142(2): 222226.

15. Sasadeusz J, Kelly H, Szer J i sur. Abnormal cervical cytology in bone marrow transplant recipients. Bone Marrow Transplant 2001; 28: 393-397.

16. Yu SC, Huang HH, Li CC, Tang JL, Lee YH, Mao TL, Kuo KT, Lin CT, Liu JH, Ko BS, Yao M. Cervical Papanicolaou Smears in Hematopoietic Stem Cell Transplant Recipients: High Prevalence of Therapy-Related Atypia during the Acute Phase Biol Blood Marrow Transplant. 2017;23(8):1367-1373.

17. Wang Y, Brinch L, Jebsen P, Tanbo T, Kirschner R. A clinical study of cervical dysplasia in long-term survivors of allogeneic stem cell transplantation. Blood Marrow Transplant. 2012;18(5):747-53.

18. Holowaty P, Miller AB, Rohan T, To T. Natural history of dysplasia of the uterine cervixJ Natl Cancer Inst. 1999;91(3):252-8. 
19. Baccarani U1, Adani GL, Montanaro D, Risaliti A, Lorenzin D, Avellini C, Tulissi P, Groppuzzo M, Currò G, Luvisetto F, Beltrami A, Bresadola V, Viale PL, Bresadola F. De novo malignancies after kidney and liver transplantations: experience on 582 consecutive cases. Transplant Proc. 2006;38(4):1135-7.

20. Poorvu PD, Barton SE, Duncan CN, London WB, Laufer MR, Lehmann LE, Marcus KJ. Use and effectiveness of gonadotropin-releasing hormone agonists for prophylactic menstrual suppression in postmenarchal women who undergo hematopoietic cell transplantation. J Pediatr Adolesc Gynecol. 2016;29(3):265-8.

21. Meirow D, Rabinovici J, Katz D, Or R, Shufaro Y, Ben-Yehuda D. Prevention of severe menorrhagia in oncology patients with treatment-induced thrombocytopenia by luteinizing hormone-releasing hormone agonist and depo-medroxyprogesterone acetate. Cancer. 2006;107(7):1634-41.

22. Lhommé C, Brault P, Bourhis JH, Pautier P, Dohollou N, Dietrich PY, Akbar-Zadeh G, Lucas C, Pico JL, Hayat M. Prevention of menstruation with leuprorelin ( $\mathrm{GnRH}$ agonist) in women undergoing myelosuppressive chemotherapy or radiochemotherapy for hematological malignancies: a pilot study. Leuk Lymphoma. 2001;42(5):1033-41. 23. Westhoff C. Depot-medroxyprogesterone acetate injection (Depo-Provera): a highly effective contraceptive option with proven longterm safety. Contraception. 2003;68(2):75-87.

24. Flowers ME, Parker PM, Johnston LJ, Matos AV, Storer B,

Bensinger WI. Comparison of chronic graft-versus-host disease after transplantation of peripheral blood stem cells versus bone marrow in allogeneic recipients: long-term follow-up of a randomized trial. Blood. 2002;100:415-9.
25. Jagasia MH, Greinix HT, Arora M, Williams KM, Wolff D, Cowen EW, Palmer J, Weisdorf D, Treister NS, Cheng GS, Kerr H, Stratton P, Duarte RF, McDonald GB, Inamoto Y, Vigorito A, Arai S, Datiles MB, Jacobsohn D, Heller T, Kitko CL, Mitchell SA, Martin PJ, Shulman H, Wu RS, Cutler CS22, Vogelsang GB, Lee SJ, Pavletic SZ, Flowers ME. National Institutes of Health Consensus Development Project on criteria for clinical trials in chronic graft-versus-host disease: I. The 2014 diagnosis and staging working group report. Biol Blood Marrow Transplant. 2015;21(3):389-401.

26.Spinelli S, Chiodi S, Costantini S, Van Lint MT, Raiola AM, Ravera GB. Female genital tract graft-versus-host disease following allogeneic bone marrow transplantation. Haematologica. 2003;88:1163-8.

27. Norian JM1, Stratton P. Labial fusion: a rare complication of chronic graft-versus-host disease. Obstet Gynecol. 2008;112(2 Pt 2):437-9. 28. Serio B, Pezzullo L, Fontana R, Annunziata S, Rosamilio R, Sessa M, Giudice V, Ferrara I, Rocco M, De Rosa G, Ricci P, Tauchmanovà L, Montuori N, Selleri C. Accelerated bone mass senescence after hematopoietic stem cell transplantation. Transl Med UniSa. 2013;5:7-137. 29. Kodama M, Komura H, Shimizu S, Hashimoto N, Mitsuda N, Kodama T, Inoue M, Ida S. Efficacy of hormone therapy for osteoporosis in adolescent girls after hematopoietic stem cell transplantation: a longitudinal study. Fertil Steril. 2011;95(2):731-5.

30.Frey Tirri B, Häusermann P, Bertz H, Greinix H, Lawitschka A, Schwarze CP, Wolff D, Halter JP, Dörfler D, Moffat R. Clinical guidelines for gynecologic care after hematopoietic SCT. Report from the international consensus project on clinical practice in chronic GVHD. Bone Marrow Transplant. 2015;50(1):3-9. 
Review Article 